Gruzelier, J. H. \& Venables, P. H. (1974) Bimodality and lateral asymmetry of skin conductance orienting activity in schizophrenics. Biological Psychiatry, 8, 55-73.

GUR, R. E. (1977) Motoric laterality imbalance in schizophrenia. Archives of General Psychiatry, 34, 33-7.

LEVY, J. (1976) A review of evidence for a genetic component in the determination of handedness. Behaviour Genetics, 6, 4, 429-53.

MCGhie, A. \& ChAPMAN, J. (1961) Disorders of attention and perception in early schizophrenia. British Journal of Medical Psychology, 34, 103-16.

Rosenthal, R. \& Bigelow, L. (1972) Brain disconnection and schizophrenia. British Journal of Psychiatry, 121, 259-64.

SChWEITZER, L., BeCKer, E. \& Welsh, H. (1978) Abnormalities of cerebral lateralization in schizophrenic patients. Archives of General Psychiatry, 35, 982-5.

Taylor, M., Greenspan, B. \& Abrams, R. (1979) Lateralized neuropsychological dysfunction in affective disorder and schizophrenia. American Journal of Psychiatry, 136, 8, 1031-4.

\section{NOMIFENSINE FOR SIDE-EFFECTS OF DEPOT NEUROLEPTICS}

Dear SIR,

Dr Bennie (Journal, February 1982, 140, 210) suggests that there may be a case for offering depressed schizophrenics on depot neuroleptics an antiparkinsonian rather than an antidepressant drug. However there is an antidepressant, nomifensine, which has definite, albeit mild, antiparkinsonian activity (Teychenne et al, 1976; Hanks and Park, 1981). It has been suggested that nomifensine may have a particular place in the management of depression in patients with Parkinson's disease (Bedard et al, 1977; Park et al, 1981) and there are certainly anecdotal reports of amelioration of neuroleptic-induced extrapyramidal symptoms and signs with nomifensine. I have recently used it with dramatic effect in a patient exhibiting extrapyramidal signs due to haloperidol overdosage.

There is little information on the effects of anticholinergic antiparkinsonian agents on mood and most of what there is refers to the elevation of mood produced by orphenadrine (Onuaguluchi, 1963; Capstick and Pudney, 1976; Johnson, 1981). Whilst there are no data specifically comparing the antidepressant effects of orphenadrine and nomifensine, there certainly seems to be a case for trying nomifensine before anticholinergic agents in the treatment of depression and perhaps also of extrapyramidal side-effects, in schizophrenic patients on depot neuroleptics.

G. W. HaNks

Sir Michael Sobell House, The Churchill Hospital, Headington, Oxford $O X 37 \mathrm{LJ}$

\section{References}

Bedard, P., Parkes, J. D. \& Marsden, C. D. (1977) Nomifensine in Parkinson's disease. British Journal of Clinical Pharmacology, 4, 187-90.

Capstick, N. \& PUdney, H. (1976) A comparative trial of orphenadrine and tofenacin in the control of depression and extrapyramidal side-effects associated with fluphenazine decanoate therapy. Journal of International Medical Research, 4, 435-40.

Hanks, G. W. \& Park, D. M. (1981) Nomifensine. In Research Progress in Parkinson's Disease (eds. F. Clifford Rose and R. Capildeo). Pp 345-50. Tunbridge Wells: Pitman Medical.

Johnson, D. A. W. (1981) Studies of depressive symptoms in schizophrenia. III. A double blind trial of orphenadrine against placebo. British Journal of Psychiatry, 139, 96-7.

Onuaguluchi, G. (1963) Assessment of drug therapy in parkinsonism. British Medical Journal, i, 443-48.

Park, D. M., Findley, L. J., Hanks, G. \& Sandler, M. (1981) Nomifensine: effect in parkinsonian patients not receiving levodopa. Journal of Neurology, Neurosurgery and Psychiatry, 44, 352-4.

Teychenne, P. F., Park, D. M., Findley, L. J., Rose, F. C. \& CALNE, D. B. (1976) Nomifensine in parkinsonism. Journal of Neurology, Neurosurgery and Psychiatry, 39, 1219-21.

\section{WHICH PATIENTS DO WELL AFTER BRIEF CRISIS ADMISSIONS?}

Dear Sir,

Recent attempts to identify characteristics associated with psychiatric treatment success in hospital have studied ward characteristics (i.e. Ellsworth et al, 1979), therapy process variables (i.e. Peake, 1979), and presenting characteristics of patients. Studies of the latter type have failed to yield a consistent pattern of results perhaps due to differences in setting and definitions of 'success' (i.e. Keithly, Samples and Strupp, 1980; Archer, Bedell and Amuso, 1980). In addition, previous studies of patient characteristics associated with treatment success have been limited by investigating only a few potential predictor variables. No study to date has investigated a large number of patient variables associated with success on a short-term psychiatric crisis unit.

One year's population of patients from the ShortTerm Assessment and Treatment Unit, Health Sciences Centre, Winnipeg, Canada were divided into 'successful' ( $n=90)$ and 'unsuccessful' $(n=48)$ based on in-hospital goal attainment scores of greater than and less than ' 50 ' respectively (Kiresuk and Sherman, 1968). The average stay for these patients was almost seven days. The groups were compared on 104 demographic, historic and diagnostic variables. Of these, only four significantly $(P<.05)$ distinguished the groups by ' $t$ ' or 'chi square' test: successful 
patients were more likely: (1) to have been taking prescribed medication and/or (2) seeing a therapist prior to hospitalization, (3) to rate their chances of staying out of hospital as being good on discharge, and (4) not to have been using non-prescribed (street) drugs prior to hospital admission. It is perhaps surprising that with well over one hundred comparisons, only four variables should significantly differentiate between successful and unsuccessful patients. In fact, by chance alone at the $P<.05$ acceptance level, five out of one hundred significant differences should be found. Thus, even those differences reported here as significant should be viewed as only possibly differentiating the groups. The most important finding of this study may be its failure to uncover discriminating variables. Nonetheless, it is useful to examine those variables found to discriminate as, taken together, they suggest a possible and distinct patient type.

\section{Catherine Elluott-Harper}

DAN HARPER

Rivian WeINERMaN

TERRY NELSON

NORMA ANDERSON

Health Sciences Centre,

Winnipeg, Manitoba, Canada

\section{References}

Archer, R. P., Bedell, J. R. \& Amuso, K. F. (1980) Personality, demographic, and intellectual variables associated with readiness for discharge from psychiatric treatment. Journal of Psychology, 104, 67-74.

EllsWorth, R. B., CASEy, N. A., Hickey, R. H., TWemlow, S. W., Collins, J. F., SChOONOVER, R. A., Hyer, L. \& Nesselroade, J. R. (1979) Some characteristics of effective psychiatric treatment programs. Journal of Consulting and Clinical Psychology, 47 (5), 799-817.

Keithly, L. J., Samples, S. J. \& Strupp, H. H. (1980) Patient motivation as a predictor of process and outcome in psychotherapy. Psychotherapy and Psychosomatic Medicine, 33 (1-2), 87-97.

Kiresuk, T. J. \& Sherman, R. E. (1968) Goal attainment scaling: A general method for evaluating comprehensive community mental health programs. Community Mental Health Journal, 4 (6), 443-53.

PEAKE, T. (1979) Therapist-patient agreement and outcome in group therapy. Journal of Clinical Psychology, 35 (3), 637-46.

\section{ECT IN MENTAL HOSPITALS}

Dear SiR,

In his otherwise excellent and well-balanced review on "The Present Status of Electroconvulsive Therapy" (Journal, October 1981, 139, 265-83), Professor R. E. Kendell, referring to the misuse of ECT in the USA,
states-"It is easy to say that such things do not happen here, but we have the scars of Ely and Whittingham to warn us that they may." I accept his point that ECT may be misused, but as the prime instigator and a major witness for the Committee of Inquiry into Whittingham Hospital (Command 4861), I object to the implication that there was any question of abuse associated with the administration of ECT at that hospital.

The Whittingham Inquiry revealed the likely presence of ill-treatment on some long-stay wards, pilfering of patients' money, and deficiencies in the nursing, medical, and general administration of the hospital. At no time was there any suggestion that ECT treatments were being misapplied.

490 Midtown Centre,

ANDRe B. MAsters

Regina, Saskatchewan,

Canada

ECT is not mentioned in the Report of the Whittingham Inquiry-Editor.

\section{Reference}

COMmand 4861 (1972) Committee of Inquiry into Whittingham Hospital. London: HMSO.

\section{ECT IN DEVELOPING COUNTRIES}

DEAR SIR,

Two years ago the only functioning ECT machine in Botswana broke down and for predominantly administrative reasons it has not yet been replaced. Botswana, a developing African country, has a national mental hospital and an extensive community service. In contrast with Dr Shukla's (Journal, December 1981, 139, 569-71) experience we have found it possible to run our psychiatric service without recourse to ECT.

Since the introduction of our community services, the average length of in-patient stay in the mental hospital has fallen considerably (66.8 days in 1978 vs. 34.4 in 1980), as has the average number of inpatients (464 in 1978 vs. 134 in 1980).

In most developing countries anaesthetists are in as short supply as psychiatrists, and unmodified ECT can be a disturbing experience for patients and staff. For us, anti-depressants and phenothiazines have proved a safe and effective alternative.

JOSEPHINE M. BEN-TOVIM DAVID I. BEN-TOVIM

Psychiatric Unit,

Jubilee Hospital,

Francistown,

Botswana 